\title{
PERAN MODERASI IDEOLOGI POLITIK TERHADAP HUBUNGAN ANTARA RELIGIOSITAS DAN KEBAHAGIAAN
}

\author{
Ais Nur Ardhy \\ Fakultas Psikologi, Universitas Indonesia, Depok \\ Email: sebuahbudaya@gmail.com
}

\begin{abstract}
Abstrak
Penelitian ini bertujuan menguji pengaruh interaksi antara ideologi politik dan religiositas terhadap kebahagiaan pada konteks Indonesia. Sebanyak 219 partisipan yang merupakan mahasiswa turut serta dalam penelitian ini. Peneliti menggunakan tiga alat ukur, yakni Satisfaction With Life Scale (SWLS), Religious Commitment Inventory - 10 (RCl-10), dan Political Ideology Scale (PIS). Hasil utama penelitian menemukan bahwa religiositas berpengaruh secara positif dan signifikan terhadap kebahagiaan $(B=0,14, p<0,01)$. Sementara itu, tidak ditemukan pengaruh signifikan dari interaksi ideologi politik dan religiositas terhadap kebahagiaan pada dimensi konservatif-liberal $(B=0,00, p>0,05)$ maupun religius-sekuler $(B=0,00, p>0,05)$. Hasil tersebut mengindikasikan bahwa semakin tinggi religiositas maka semakin tinggi pula kebahagiaan individu. Sementara itu, ideologi politik tidak memiliki pengaruh moderasi terhadap hubungan antara religiositas dan kebahagiaan. Temuan ini tidak mendukung temuan sebelumnya yang menunjukkan adanya peran moderasi ideologi politik dalam hubungan religiositas dan kebahagiaan. Hal ini dapat disebabkan oleh beberapa faktor seperti konseptualisasi religiositas yang berbeda dan perbedaan perseberan ideologi politik di Indonesia dengan negara tempat penelitian-peneltian sebelumnya dilakukan.
\end{abstract}

Kata kunci: ideologi politik; kebahagiaan; kepuasan hidup; religiositas

\begin{abstract}
This study aims to examine the moderating effect of political ideology on the relationship of religiosity and happiness in Indonesian context. 219 students of University of Indoneisa participated in this study. Three measurements were used: Satisfaction With Life Scale (SWLS), Religious Commitment Inventory - 10 (RCl-10), dan Political Ideology Scale (PIS). The main results of the study found that religiosity had a positive and significant effect on happiness $(B=0.14, p<0.01)$. Meanwhile, no significant moderartion effect was found, either in the conservative-liberal's $(B=0.00, p>0.05)$ or in religious-secular's political ideology categorization $(B=0.00, p>0.05)$. These results indicate that the higher the religiosity the higher the happiness of the individual. Meanwhile, political ideology has no significant moderation effect on the relationship of religiosity and happiness. Thus, this study did not support past studies. It might be attributed to the difference in how religiosity is operationalized and in the political situations that might cause the difference on the role of political ideology.
\end{abstract}

Keywords: happiness; life-satisfacton; political ideology; religiostity 


\section{Pendahuluan}

Kebahagiaan seringkali dianggap sebagai salah satu tujuan utama dalam hidup, namun kebahagiaan merupakan konsep yang abstrak dan sulit untuk dimengerti. Keadaan ini memicu munculnya ketertarikan peneliti sosial untuk mengetahui lebih dalam mengenai kebahagiaan (Diener, 1984; Ryff, 1989; Seligman, Steen, Park, \& Peterson, 2005). Salah satu teori yang seringkali digunakan untuk mendefinisikan kebahagiaan adalah subjective well-being (Diener, 1984). Penelitian mengenai kebahagiaan atau subjective well-being dalam 2 dekade terakhir banyak membahas mengenai faktor yang dapat memengaruhi kebahagiaan (Bixter, 2015; Fujita, Diener \& Sandvik, 1991; Horley \& Laavery, 1995; Lucas, 2005; Mroczek \& Spiro, 2005; Peterson \& Seligman, 2004; Steger \& Frezier, 2005). Salah satu faktor yang dapat memengaruhi tingkat kebahagiaan khususnya subjective wellbeing adalah religiositas (French \& Joseph, 1999; Steger \& Frezier 2005; Soydemir, Batisda \& Gozales 2004).

Religiositas didefinisikan sebagai derajat keimanan individu terhadap nilai, ajaran, dan praktik dalam komunitas ketuhanan (agama) yang dilihat melalui penerapan dalam kehidupan personal sehari-hari (Worthington, 1988). Religiositas berpengaruh pada kebahagiaan inidividu karena ajaran agama memberikan nilai yang memicu muculnya emosi positif (Peterson \& Seligman, 2004), mengajarkan individu mengenai self-control sehingga mengurangi emosi negatif (McCullough \& Willoughby, 2009), serta memberikan makna dan tujuan dalam hidup yang dapat berdampak pada bertambahnya kepuasan hidup (Steger \& Frezier, 2005). Dapat dikatakan bahwa agama berpengaruh terhadap keadaan emosi dan kepuasan hidup yang merupakan faktor penyusun kebahagiaan.

Meskipun beberapa penelitian (lihat Taylor, Funk, \& Craighill, 2006, Steger \& Frazier, 2005) telah menemukan pengaruh religiositas terhadap kebahagia- an, pengaruh ini tidak terjadi pada setiap individu. Salah satu perbedaan individu yang memberikan pengaruh pada hubungan antara religiositas dan kebahagiaan adalah ideologi politik. Carney, Jost, Gosling, dan Potter (2008) menjelaskan ideologi politik sebagai posisi yang diambil oleh individu dalam sebuah dimensi abstrak yang biasa disebut sayap kiri dan kanan dengan perbedaan nilai yang mendasar. Dalam konteks negara barat khususnya Amerika, sayap kanan dan kiri seringkali disebut ideologi konservatif dan liberal yang memiliki perbedaan pada (a). Penerimaan atau penolakan terhadap kesenjangan, dan (b). preferensi terhadap perubahan sosial atau mempertahankan status quo dalam sistem sosial (Carney dkk., 2008). Penganut sayap kanan (konservatif) lebih menerima adanya kesenjangan dan ingin tetap mempertahankan status quo dalam sistem sosial, sementara penganut sayap kiri (liberal) beranggapan sebaliknya (Schlenker, Chamber \& Le, 2012).

Napier dan Jost (2008) menyebutkan bahwa ideologi konservatif memiliki hubungan positif dengan kepuasan hidup dan kebahagiaan yang dapat dijelaskan melalui system justification theory. Selain itu, individu dengan ideologi konservatif lebih mudah untuk melakukan positive adjustment dan memiliki mental health yang lebih tinggi daripada penganut ideologi liberal. Positive adjustment dan mental health merupakan faktor yang membangun kepuasan hidup dan kebahagiaan (Schlenker dkk., 2012).

Bixter (2015) melakukan penelitian mengenai religiositas, ideologi politik dan kebahagiaan pada masyarakat Amerika, dan menemukan bahwa pengaruh religiositas terhadap kebahagiaan hanya signifikan pada individu dengan ideologi politik konservatif. Hubungan ini muncul karena adanya kesamaan sikap dan nilai yang dimiliki oleh penganut konservatif dengan individu yang religius seperti menghargai dan menjaga tradisi, pemisahan yang jelas antara baik dan benar, 
kesetiaan terhadap keluarga dan kelompok sosial, serta penolakan terhadap tingkahlaku yang dianggap negatif (Bixter, 2015). Penelitian Bixter (2015) menunjukkan bahwa religiositas dan ideologi politik berinteraksi dalam memprediksi tingkat kebahagiaan, terutama bagi penganut konservatif. Sementara itu, hanya ditemukan interaksi kecil antara religiositas dan ideologi politik liberal dalam memprediksi tingkat kebahagiaan. Dapat dikatakan juga bahwa religiositas memiliki pengaruh lebih besar terhadap tingkat kebahagiaan individu dengan ideologi politik konservatif dibanding individu dengan ideologi politik liberal.

Meskipun banyak penelitian yang telah menemukan adanya hubungan antara religiositas, ideologi politik dan kebahagiaan, penelitian-penilitian ini masih terbatas pada negara-negara barat, khususnya Amerika yang memiliki kategorisasi konservatif-liberal dalam ideologi politiknya (Bixter, 2015; Choma, Busseri, \& Sadava, 2009; Napier \& Jost, 2008; Schlenker dkk., 2012; Taylor dkk., 2006). Apakah hasil yang sama akan ditemukan pada konteks yang berbeda (negara dengan kategorisasi ideologi politik yang berbeda)? Stavrova dan Luhman (2016) menyatakan bahwa hubungan antara ideologi politik dan kebahagiaan dipengaruhi oleh ideologi yang lebih dominan dalam suatu Negara. Temuan Stavrova dan Luhman (2016) mengindikasikan adanya pengaruh konteks dalam hubungan ideologi dan kebahagiaan.

Penelitian ini dilakukan untuk melihat hubungan antara religiositas, ideologi politik dan kebahagiaan di Indonesia yang memiliki konteks lain, yaitu kategorisasi ideologi politik yang berbeda dari penelitian sebelumnya. Dalam konteks Indonesia, selain konservatif-liberal, ideologi politik juga dibagi melalui nilai yang diyakini masyarakat mengenai agama dan negara, dan bagaiman pemerintah seharusnya mengatur ekonomi negara (Muluk, dkk., 2018). Berdasarkan nilai tersebut ideologi politik terbagi kedalam ideologi politik religius dan sekuler, serta ideologi politik kapitalis dan sosialis. Penganut ideologi religius adalah kelompok individu yang menginginkan aturan agama menjadi dasar dari aturan negara karena mereka menganggap kepentingan dunia dan akhirat tidak seharusnya dipisahkan, sementara penganut sekuler percaya bahwa kepentingan akhirat merupakan urusan masing-masing individu dan menolak untuk menjadikan aturan agama sebagai dasar negara (Ismail, 1995). Dalam penelitian ini ideologi politik yang akan dilihat adalah dimensi ideologi politik konservatif-liberal dan religius-sekuler.

Penelitian ini berupaya mereplikasi penelitian Bixter (2015) mengenai interaksi antara religiositas dan ideologi politik terhadap kebahagiaan pada konteks Indonesia. Religiositas dalam penelitian ini dilihat melalui komitmen dan ketaatan individu pada agamanya. Sementara kebahagiaan dilihat melalui kepuasan individu terhadap hidupnya secara keseluruhan. Kemudian, penelitian ini menggunakan dimensi ideologi politik konservati-liberal dan menambahakan dimensi ideologi politik religius-sekuler untuk melihat ideologi politik masyarakat Indonesia. Apabila dilihat dari penelitianpenelitian sebelumnya yang menemukan bahwa penganut ideologi politik konservatif lebih bahagia daripada penganut liberal, peneliti memiliki argumen bahwa pengaruh religiositas terhadap kebahagiaan akan lebih besar pada penganut ideologi religius dibanding penganut ideologi sekuler. Penelitian pada konteks Indonesia akan menjadi temuan lain yang dapat menambah dinamika teoritis dari hubungan antar variabel yang digunakan.

Berdasarkan bukti yang didapatkan dari penelitian sebelumnya, penelitian ini memiliki hipotesis bahwa hubungan antara religiositas dan kebahagiaan lebih kuat pada penganut ideologi konservatif dan religius, dan lebih lemah pada penganut ideologi liberal dan sekuler.

\section{Metode Penelitian}

Sampel Penelitian. Sampel yang digunakan dalam penelitian ini adalah 
mahasiswa aktif yang berkuliah di Universitas Indonesia. Teknik pengambilan sampel dalam penelitian ini adalah accidental sampling yang disesuaikan dengan karakteristik sampel yang telah ditentukan, yaitu mahasiswa Universitas Indonesia. Dalam accidental sampling, sampel yang digunakan adalah sampel yang dapat dijangkau oleh peneliti. Partisipan dalam studi ini berjumlah 219 partisipan yang terdiri dari 133 perempuan dan 86 laki-laki, 165 beragama Islam 54 beragama selain Islam (Kristen, Katholik, Hindu, Budha), dan memiliki rentang usia 18-26 tahun.

Instrumen penelitian. Kebahagiaan atau SWB dilihat melalui alat ukur satisfaction with life scale (SWLS; Diener, Emmons, Larsen, \& Griffin, 1985). Alat ukur ini terdiri dari 5 item dengan skala Likert 7 poin (1= "sangat tidak setuju", 7= "sangat setuju"). Setiap item dalam alat ukur ini mengukur tingkat kepuasan hidup individu secara keseluruhan dan memberikan kebebasan pada individu untuk menentukan kriteria dan standar dalam pengisian ("Saya puas dengan kehidupan saya"). Setelah dilakukan penerjemahan kedalam bahasa Indonesia dan dilakukan uji reliabilitas menggunakan teknik Cronbach's Alpha, koefisien reliabilitas yang didapatkan adalah $\alpha$ : 0,786 .

Religiositas pada studi ini diukur menggunkan Religious Commitment Inventory-10 (RCl-10; Worthington dkk., 2003). RCl-10 disusun untuk mengukur komitmen individu terhadap agamanya, yang dijabarkan melalui derajat kepatuhan individu terhadap nilai dan kepercayaan yang diajarkan agama, praktik keagamaan, dan bagaimana individu menerapkannya dalam kehidupan sehari-hari (Worthington dkk., 2003). Alat ukur ini terdiri dari 10 item dengan skala Likert 7 poin (1= "sangat tidak setuju", 7= "sangat setuju"; "Keyakinan agama memengaruhi saya menghadapi segala hal dalam hidup"). Alat ukur ini pernah digunakan dan dialihbahasakan ke dalam Bahasa Indonesia oleh Rosalina (2013), kemudi- an digunakan kembali oleh Devany (2016) dan memiliki koefisien reliabilitas 0,901 . Pengujian ulang reliabilitas pada studi ini menunjukkan koefisien reliabilitas a: 0,801 .

Ideologi politik di Indonesia diukur menggunakan Political Ideology Scale yang dikembangkan oleh Muluk, dkk. (2018). Alat ukur ini terdiri dari 20 item dan 3 dimensi: konservatif-liberal, religiussekuler, sosialis-kapitalis dengan skala Likert 7 poin (1= "sangat tidak setuju", 7= "sangat setuju"). Dalam studi ini, dimensi yang diikutsertakan oleh peneliti dalam pengukuran adalah dimensi konservatifliberal, dan religius-sekuler yang berada pada item nomer 1-11 dari alat ukur ini ("Indonesia tidak perlu mengakui hak-hak LGBT", "Indonesia perlu segera menjadi negara agama"). Hasil uji reliabilitas menunjukkan koefisien reliabilitas pada dimensi konservatif-liberal sebesar $\alpha$ : 0,781 , sementara pada dimensi religiussekuler dengan angka $\alpha$ : 0,775.

Prosedur penelitian. Pelaksanaan penelitian dilakukan pada bulan Mei 2018. Peneliti menyebarkan kuesioner secara dalam bentuk hard-copy dan secara online mulai tanggal 1-17 Mei 2018. Kuesioner dalam bentuk hard-copy disebarkan di lingkungan Universitas Indonesia dan mendapatkan 109 partisipan yang bersedia untuk mengisi kuesioner. Secara online, peneliti menyebarkan kuesioner melalui media sosial dan aplikasi chatting, dan mendapatkan 122 partisipan yang mau mengisi kuesioner, namun 12 di antaranya tidak dapat diikutsertakan dalam pengolahan data. Sehingga total data yang diikutsertakan dalam pengolahan ada 219 data. Pengolahan data dilakukan dengan menggunakan SPSS versi 24 dan teknik analisis deskriptif, korelasi dan regresi.

\section{Hasil Penelitian}

Melalui data yang terkumpul, peneliti melakukan analisis deskriptif variabel utama penelitian untuk memberikan gambaran nilai statistik variabel utama penelitian. Hasil analisis deskriptif varia 
Tabel 1. Gambaran Nilai Statistik Variabel Utama Penelitian

\begin{tabular}{lccccc}
\hline \multirow{1}{*}{ Variabel } & \multicolumn{5}{c}{ Total Sampel: 219 } \\
\cline { 2 - 6 } & $\begin{array}{c}\text { Rentang } \\
\text { Skor }\end{array}$ & Mean & SD & Minimun & Maximum \\
\hline Religiositas & $10-70$ & 47,45 & 9,75 & 20 & 68 \\
IP Konservatif- & $5-35$ & 19,05 & 6,56 & 5 & 35 \\
Liberal & & & & & \\
IP Religius-Sekuler & $6-42$ & 19,08 & 7,46 & 6 & 39 \\
Kepuasan Hidup & $5-35$ & 22,90 & 5,05 & 11 & 34 \\
\hline
\end{tabular}

Tabel 2. Zero Order Correlation - Korelasi antar Variabel Penelitian

\begin{tabular}{|c|c|c|c|c|c|c|}
\hline \multirow{2}{*}{ Variabel } & \multicolumn{6}{|c|}{ Total Sampel $=219$} \\
\hline & 1 & 2 & 3 & 4 & 5 & 6 \\
\hline \multicolumn{7}{|l|}{ Variabel Demografis } \\
\hline 1. Agama & 1 & & & & & \\
\hline 2. Jenis Kelamin & 0,00 & 1 & & & & \\
\hline 3. Usia & $-0,113$ & 0,118 & 1 & & & \\
\hline \multicolumn{7}{|l|}{ Variabel Bebas } \\
\hline 4. Religiositas & 0,056 & 0,024 & $-0,002$ & 1 & & \\
\hline \multicolumn{7}{|l|}{ Variabel Moderator } \\
\hline $\begin{array}{l}\text { 5. Ideologi Politik } \\
\text { Konservatif-Liberal }\end{array}$ & $-.0,02$ & $-0,057$ & 0,090 & $0,566^{* *}$ & 1 & \\
\hline $\begin{array}{l}\text { 6. Ideologi Politik Religius- } \\
\text { Sekuler }\end{array}$ & $-0,148^{*}$ & 0,001 & 0,062 & $0,483^{* *}$ & $0,715^{\star *}$ & 1 \\
\hline \multicolumn{7}{|l|}{ Variabel Terikat } \\
\hline 7. Kepuasan Hidup & $-0,005$ & 0,020 & $-0,065$ & $0,303^{* *}$ & $0,180^{* *}$ & $0,167^{*}$ \\
\hline
\end{tabular}

bel utama penelitian dapat dilihat pada tabel 1.

Variabel religiositas memiliki rentang skor yang berada diantara $10-$ 70. Nilai rata-rata seluruh partisipan adalah 47,45 $(\mathrm{SD}=9,75)$ dengan skor terendah yang diperoleh partisipan adalah 20 dan skor tertingginya 68. Variabel ideologi politik pada dimensi konservatif-liberal memiliki rentang skor yang berada diantara $5-35$. Nilai ratarata seluruh partisipan adalah 19,05 (SD $=6,56$ ), dengan skor terendah yang diperoleh partisipan adalah 5 dan skor tertingginya 35 . Sementara dimensi religius-sekuler memiliki rentang skor yang berada diantara $6-42$. Nilai ratarata seluruh partisipan adalah 19,08 (SD $=7,45)$, dengan skor terendah yang diperoleh partisipan adalah 6 dan skor tertingginya 39. Variabel kepuasan hidup memiliki rentang skor yang berada diantara $5-35$. Nilai rata-rata seluruh partisipan adalah 22,90 (SD $=5,04)$, dengan skor terendah yang diperoleh partisipan adalah 11 dan skor tertingginya 34.

Analisis korelasi dilakukan untuk melihat hubungan antar variabel dalam penelitian. Selain itu analisis ini juga dilakukan untuk memenuhi syarat analisis moderasi, yaitu adanya hubungan signifikan pada variabel utama penelitian. Hasil analisis korelasi dari seluruh variabel penelitian dapat dilihat pada tabel 2 .

Hasil analisis korelasi menggunakan teknik Pearson Product Moment menunjukkan bahwa agama, jenis kelamin, dan usia tidak memiliki hubungan yang signifikan dengan kepuasan hidup dan 
Tabel 3. Hasil Analisis moderasi antara Religiositas dan Dimensi Ideologi Politik Konservatif-Liberal terhadap Kepuasan Hidup

\begin{tabular}{|c|c|c|c|c|c|c|c|c|}
\hline \multirow{2}{*}{ Variabel } & \multicolumn{8}{|c|}{ Total Sampel $=219$} \\
\hline & $B$ & SE B & $\mathrm{T}$ & $\mathrm{P}$ & $\mathrm{Cl}$ & $\mathrm{R}$ & R2 & $\mathrm{F}$ \\
\hline Model & & & & & & 0,31 & 0,09 & 7,41 \\
\hline 1. Religiositas & 0,14 & 0,04 & 3,49 & 0,00 & $0,06,0,23$ & & & \\
\hline 2. IP Konservatif-Liberal & 0,01 & 0,06 & 0,21 & 0,83 & $-0,11,0,13$ & & & \\
\hline $\begin{array}{l}\text { 3. Religiositas * } \\
\text { IP Konservatif-Liberal }\end{array}$ & 0,00 & 0,00 & $-0,67$ & 0,50 & $-0,01,0,00$ & & & \\
\hline
\end{tabular}

religiositas. Sementara itu, ditemukan hubungan negatif dan signifikan antara agama partisipan dengan ideologi politik religius-sekuler, dengan $r=-0,148$, $p<0,05$.

Hasil analisis korelasi antara religiositas dan kepuasan hidup menunjukkan koefisien $r=0,303, p<0,01$, hal ini berarti religiositas memiliki hubungan secara positif dan signifikan dengan kepuasan hidup. Hubungan positif dan signifikan juga ditemukan pada hasil analisis antara ideologi politik konservatif-liberal dan kepuasan hidup, dengan $r=0,18, p<0,01$, dan hasil analisis antara ideologi politik religius-sekuler dan kepuasan hidup dengan $r=0,167, p<0,05$. Hasil analisis antara religiositas dan 2 dimensi ideologi politik menunjukkan bahwa korelasi antara religiositas dan dimensi konservatifliberal ideologi politik memiliki hubungan yang positif dan signifikan. dengan $r=$ $0,566, p<0,01$. Hubungan positif dan signifikan juga ditemukan dari hasil analisis korelasi antara religiositas dan dimensi religius-sekuler ideologi politik, dengan $r$ $=0,483, p<0,01$.

Pengujian hipotesis Studi ini dilakukan menggunakan program PROCESS yang dikembangkan oleh Hayes (2013). Hasil analisis moderasi dimensi ideologi politik konservatif-liberal secara keseluruhan dapat dilihat pada tabel 3 .

Hasil analisis menunjukkan bahwa religiositas, dan dimensi ideologi politik konservatif-liberal dapat menjelaskan varians pada kepuasan hidup sebesar $9 \%, \mathrm{R}^{2}=0,09, \mathrm{~F}(3,215)=7,41, p<0,01$. Kemudian, hasil analisis terhadap efek individual dari masing-masing variabel prediktor menunjukkan bahwa religiositas berpengaruh secara positif dan signifikan terhadap kepuasan hidup ( $B=0,14,95 \%$ $\mathrm{Cl}[0,06,0,23], p<0,01)$. Sementara itu, dimensi ideologi politik konservatif-liberal tidak memiliki pengaruh yang signifikan terhadap kepuasan hidup ( $B=0,01,95 \%$ $\mathrm{Cl}[-0,11,0,13], p>0,05)$.

Selanjutnya, hasil analisis regresi moderasi menunjukkan interaksi antara religiositas dan ideologi politik konservatif-liberal tidak memiliki pengaruh yang signifikan terhadap kepuasan hidup $(B=$ $0,00,95 \%$ Cl $[-0,01,0,00], p>0,05)$. Pengaruh interaksi ini tidak memberikan peningkatan varians yang signifikan terhadap tingkat kebahagiaan, dengan $\Delta \mathrm{R}^{2}$ $=0,00, F(1,215)=0,46, p>0,05$.

Analisis moderasi pada dimensi dimensi ideologi politik religius-sekuler memasukkan agama sebagai covariat. Agama diikutsertakan karena memiliki hubungan yang signifikan dengan dimensi ideologi politik religius-sekuler. Tabel 4 menampilkan hasil analisis moderasi dimensi ideologi politik religius-sekuler secara keseluruhan.

Hasil analisis menunjukkan bahwa religiositas dan dimensi ideologi politik religius-sekuler dapat menjelaskan varians pada kepuasan hidup sebesar $9 \%, \mathrm{R}^{2}=$ $0,09, F(4,214)=5,79, p<0,01$. Kemudian, hasil analisis terhadap efek individual dari masing-masing variabel prediktor menunjukkan bahwa religiositas berpengaruh secara positif dan signifikan terhadap kepuasan hidup ( $B=0,14,95 \%$ Cl $[0,06,0,22], p<0,01)$. Sementara itu, 
Tabel 4. Hasil Analisis moderasi antara Religiositas dan Dimensi Ideologi Politik Religius-Sekuler terhadap Kepuasan Hidup

\begin{tabular}{lcccccccc}
\hline \multirow{2}{*}{ Variabel } & \multicolumn{8}{c}{ Total Sampel = 219 } \\
\cline { 2 - 8 } & $\mathrm{B}$ & $\mathrm{SE} \mathrm{B}$ & $\mathrm{T}$ & $\mathrm{P}$ & $\mathrm{Cl}$ & $\mathrm{R}$ & $\mathrm{R} 2$ & $\mathrm{~F}$ \\
\hline Model & & & & & & 0,31 & 0,09 & 5,79 \\
1. Religiositas & 0,14 & 0,04 & 3,57 & 0,00 & $0,06,0,22$ & & & \\
2. IP Religius-Sekuler & 0,03 & 0,05 & 0,58 & 0,55 & $-0,07,0,13$ & & & \\
3. Religiositas * & 0,00 & 0,00 & $-1,10$ & 0,27 & $-0,01,0,00$ & & & \\
$\quad$ IP Religius-Sekuler & & & & & & & & \\
4. Agama & $-0,11$ & 0,73 & $-0,15$ & 0,87 & $-1,56,1,33$ & & & \\
\hline
\end{tabular}

Tabel 5. Hasil Analisis moderasi antara Religiositas dan Dimensi Ideologi Politik Religius-Sekuler terhadap Kepuasan Hidup

\begin{tabular}{|c|c|c|c|c|c|c|c|c|}
\hline \multirow{2}{*}{ Variabel } & \multicolumn{8}{|c|}{ Total Sampel $=219$} \\
\hline & $B$ & SE B & $\mathrm{t}$ & $P$ & $\mathrm{Cl}$ & $\mathrm{R}$ & $\mathrm{R} 2$ & $\mathrm{~F}$ \\
\hline Model & & & & & & 0,31 & 0,09 & 5,79 \\
\hline 1. Religiositas & 0,14 & 0,04 & 3,57 & 0,00 & $0,06,0,22$ & & & \\
\hline 2. IP Religius-Sekuler & 0,03 & 0,05 & 0,58 & 0,55 & $-0,07,0,13$ & & & \\
\hline $\begin{array}{l}\text { 3. Religiositas * } \\
\text { IP Religius-Sekuler }\end{array}$ & 0,00 & 0,00 & $-1,10$ & 0,27 & $-0,01,0,00$ & & & \\
\hline 4. Agama & $-0,11$ & 0,73 & $-0,15$ & 0,87 & $-1,56,1,33$ & & & \\
\hline
\end{tabular}

dimensi ideologi politik religius-sekuler tidak memiliki pengaruh yang signifikan terhadap kepuasan hidup ( $B=0,03,95 \%$ $\mathrm{Cl}[-0,07,0,13], p>0,05)$.

Hasil analisis regresi moderasi dari interaksi antara religiositas dan ideologi politik konservatif-liberal juga tidak memiliki pengaruh yang signifikan terhadap kepuasan hidup $(B=0,00,95 \% \mathrm{Cl}$ $[-0,01,0,00], p>0,05)$. Pengaruh interaksi ini juga tidak memberikan peningkatan varians yang signifikan terhadap tingkat kebahagiaan, dengan $\Delta \mathrm{R}^{2}=0,01, F(1$, $214)=1,21, p>0,05$. Tabel 4 menggambarkan hasil analisis moderasi dimensi ideologi politik religius-sekuler secara keseluruhan.

Berdasarkan tabel 4 dan 5, dapat disimpulkan bahwa tingkat religiositas memengaruhi tingkat kepuasan hidup, sehingga hipotesis pertama diterima. Akan tetapi ideologi politik, baik dimensi konservatif-liberal maupun religius-sekuler tidak memiliki pengaruh terhadap tingkat kepuasan hidup sehingga hipotesis kedua ditolak. Selain itu, kedua dimensi ideologi politik juga tidak memiliki pengaruh terhadap hubungan antara religiositas dan kepuasan hidup, dengan kata lain interaksi antara ideologi politik dan religiositas tidak dapat memprediksi tingkat kepuasan hidup, sehingga hipotesis ketiga juga ditolak.

\section{Diskusi}

Penelitian ini memiliki tujuan untuk melihat apakah pengaruh interaksi antara ideologi politik dan religiositas terhadap tingkat kepuasan hidup seperti yang ditemukan oleh Bixter (2015) dapat diterapkan pada konteks Indonesia. Melalui bab-bab sebelumnya, peneliti memiliki argumen bahwa pengaruh interaksi antara ideologi politik dan religiositas terhadap tingkat kepuasan hidup dapat ditemukan juga pada konteks Indonesia. Hasil yang didapatkan dari penelitian ini menunjukkan bahwa tidak ada pengaruh 
signifikan dari interaksi antara ideologi politik dan religiositas terhadap tingkat kepuasan hidup tidak dapat ditemukan juga pada konteks Indonesia. Dapat dikatakan juga bahwa ideologi politik pada dimensi konservatif-liberal, maupun religius-sekuler tidak memiliki pengaruh pada kuat lemahnya hubungan antara religiositas dan kebahagiaan.

Terdapat beberapa faktor yang dapat menjelaskan tidak adanya pengaruh interaksi antara ideologi politik dan religiositas terhadap kepuasan hidup pada konteks Indonesia. Pertama, pembagian ideologi politik di Indonesia yang masih belum konklusif. Salah satu cara individu untuk mendapatkan ideologi politiknya adalah dengan ideo attribution effect, yaitu mengikuti ideologi yang dianut oleh elit politik ataupun partai politik (Skitka \& Washburn, 2016). Akan tetapi, partai politik di Indonesia yang seharusnya menjadi rumah bagi ideologi politik (seperti Republikan untuk konservatif, dan Demokrat untuk liberal di Amerika) tidak dipisahkan oleh ideologi yang mereka bawa. Sebagai contohnya, diambil dari Kompas.com (2018) yang membahas wacana pembagian pada pemilu 2019 nanti. Ada 3 poros utama yang mungkin akan bersaing pada pemilu 2019, yaitu poros Jokowi, Prabowo dan Demokrat. Ketiga poros ini berisikan koalisi partai yang memiliki basis ideologi yang berbeda. Poros Jokowi terdiri dari koalisi partai PDIP, Nasdem, Hanura, Golkar yang berbasis sekuler dan PPP yang berbasis agama. Poros Prabowo terdiri dari koalisi partai Gerindra yang berbasis sekuler dan PKS yang berbasis agama. Poros Demokrat merupakan koalisi dari partai demokrat dengan basis sekuler, PKB dengan basis agama, dan PAN yang memiliki basis diantara sekuler dan agama. Keadaan ini menyebabkan ideological script hypothesis (Skitka \& Washburn, 2016) tidak dapat diterapkan karena 3 poros yang menjadi kiblat politik bagi masyarakat, tidak berada pada salah satu sayap ideologi politik secara spesifik. Efek dari keadaan ini membuat masyara- kat tidak tahu ideologi politik seperti apa yang dapat dianut oleh masyarakat. Penelitian lebih dalam mengenai pemahaman masyarakat terhadap ideologi politik perlu dilakukan.

Kedua, Stavrova dan Luhman (2016) menyatakan bahwa hubungan antara ideologi politik dan kebahagiaan dipengaruhi oleh ideologi politik yang lebih dominan dalam suatu negara. Pengaruh ideologi konservatif terhadap tingkat kebahagiaan hanya ditemukan pada negara yang perpolitikan dalam negara didominasi oleh penganut konservatif seperti Amerika, sementara pada negara yang perpolitikan negaranya didominasi oleh penganut liberal, pengaruh dari ideologi konservatif terhadap kebagiaan tidak signifikan sehingga tidak memunculkan perbedaan tingkat kebahagiaan antara penganut konservatif dan liberal. Persebaran partai politik sebagian besar memiliki dasar ideologi sekuler yang lebih dekat dengan ideologi liberal. Berdasarkan persebaran ini, dapat dikatan bahwa penganut sekuler/liberal lebih mendominasi dalam perpolitikan Indonesia dan membuat pengaruh ideologi konservatif terhadap kebahagiaan tidak signifikan, sehingga tidak ditemukan adanya perbedaan kepuasan hidup antara penganut ideologi politik yang berbeda.

Ketiga, adanya kemungkinan bahwa definisi operasional mengenai religiositas di Indonesia dengan definisi yang telah ada memiliki perbedaan. Religiositas pada penelitian ini dioperasionalkan menggunakan ketaatan dan kepercayaan individu terhadap agamanya. Definisi ini mungkin sudah dapat mewakili religiositas di negara tempat penelitian sebelumnya dilakukan yaitu Amerika karena masyarakat di negara tersebut tidak menganggap agama sebagai bagian penting kehidupan sehingga frekuensi ketaatan menjalankan ibadah sudah bisa menggambarkan tingkat religiositas. Sementara pada konteks Indonesia, sebagian besar masyarakat menjadikan agama sebagai bagian penting dalam hidup mereka, sehingga apabila tingkat religiositas 
diukur melalui ketaatan dan kepercayaan individu terhadap agama saja maka besar kemungkinan individu yang memliki perbedaan ideologi politik akan mendapatkan skor religiositas yang sama (kedua kelompok sama-sama religios). Penelitian mengenai sudut pandang masyarakat Indonesia mengenai religiositas perlu dilakukan untuk mengkonfirmasi hal ini dan menemikan indikator yang lebih tepat untuk membedakan tingkatan religiositas pada berbadai kelompok ideeologi politik.

Keempat, meskipun ditemukan hubungan yang signifikan antara religiositas dan ideologi politik, arah hubungan dan varians yang memengaruhi hubungan antar kedua variabel masih belum diketahui. Penjelasan mengenai hubungan kedua variabel hanya sebatas penjelasan mengenai adanya kesamaan antara religiositas dan ideologi konservatif, namun belum ada penjabaran mengenai bagaimana religiositas dapat memengaruhi ideologi politik ataupun sebaliknya. Penelitian lebih lanjut mengenai hubungan antara religiositas dan ideologi politik perlu dilakukan untuk melihat pola hubungan secara lebih jelas dan mengetahui bagaimana kedua variabel berinteraksi dalam memengaruhi kebahagiaan.

Penelitian ini juga memiliki beberapa limitasi yaitu, Sampel yang sedikit dan kurang representatif. Jumlah total sampel pada penelitian ini adalah 219 partisipan. Jumlah ini dirasa peneliti masih kurang untuk dapat melihat pengaruh interaksi antara ideologi politik dan religiositas terhadap tingkat kepuasan hidup. Kemudian, partisipan penelitian yang merupakan mahasiswa juga menjadi salah satu keterbatasan penelitian. Cornelis, Van Hiel, Roets, dan Kossowska (2009) menyebutkan bahwa kelompok umur mahasiswa (18-24 tahun) rata-rata memiliki ideologi yang cenderung liberal. Kecenderungan ini menyebabkan analisis yang dilakukan tidak mampu melihat interaksi antara ideologi politik konservatif/religius dan re- ligiositas karena mayoritas partisipan memiliki ideologi liberal/sekuler. Selain itu, alat ukur yang digunakan dalam mengukur religiositas merupakan adaptasi dari alat ukur yang dikembangkan di Amerika sehingga masih diragukan apakah alat ukur yang digunakan sudah mampu mewakili religiositas dalam konteks Indonesia.

\section{Kesimpulan}

Penelitian ini menunjukkan bahwa tingkat religiositas berpengaruh terhadap tingkat kepuasan hidup. Artinya, semakin tinggi tinggi tingkat religiositas, maka tingkat kepuasan hidup akan meningkat. Sementara itu tidak ditemukan pengaruh yang signifikan dari ideologi politik pada dimensi konservatif-liberal, maupun religius-sekuler terhadap kepuasan hidup. Artinya, ideologi politik yang dianut oleh individu pada dimensi konservatif-liberal, maupun religius-sekuler tidak dapat memprediksi tingkat kepuasan hidup masyarakat Indonesia. Kemudian hasil analisis mengenai interaksi antara ideologi politik pada dimensi konservatifliberal, maupun religius-sekuler dan religiositas terhadap tingkat kepuasan hidup juga ditemukan tidak signifikan. Artinya, jenis ideologi politik yang dianut oleh individu tidak memiliki pengaruh terhadap hubungan antara religiositas dan kepuasan hidup.

\section{Daftar Pustaka}

Bixter, M. T. (2015). Happiness, political orientation, and religiosity. Personality and Individual Differences, 72, 7-11. doi: 10.1016/j.paid.2014.08.010

Carney, D. R., Jost, J. T., Gosling, S. D., \& Potter, J. (2008). The secret lives of liberals and conservatives: Personality profiles, interaction styles, and the things they leave behind. Political Psychology, 29(6), 807-840. doi: 10.1111/j.14679221.2008.00668.x

Cornelis, I., Van Hiel, A., Roets, A., \& Kossowska, M. (2009). Age 
differences in conservatism: Evidence on the mediating effects of personality and cognitive style. Journal of Personality, 77(1), 51-88. Doi: 10.1111/j.1467-6494.2008.00538.x

Choma, B. L., Busseri, M. A., \& Sadava, S. W. (2009). Liberal and conservative political ideologies: Different routes to happiness?. Journal of Research in Personality, 43(3), 502-505. Doi: 10.1016/j.jrp.2008.12.016

Devany, K. (2017) Perbandingan religiusitas dan spiritualitas antara dewasa muda dengan orangtua berbeda agama dan dewasa muda dengan orangtua seagama. (Unpublished undergraduate thesis). Universitas Indonesia, Depok.

Diener, E. (1984). Subjective well-being. Psychological Bulletin, 95, 542-575. doi: 10.1037//0033-2909.95.3.542

Diener, E., Emmons, R. A., Larsen, R. J., \& Griffin, S. (1985). The satisfaction with life scale. Journal of Personality Assessment, 49(1), 71-15. doi: 10.1207/s15327752jpa4901_13

Fujita, F., Diener, E., \& Sandvik, E. (1991). Gender differences in negative affect and well-being: the case for emotional intensity. Journal of personality and social psychology, 61(3), 427. doi: 10.1037//0022-3514.61.3.427

French, S., \& Joseph, S. (1999). Religiosity and its association with happiness, purpose in life, and selfactualisation. Mental Health, Religion \& Culture, 2(2), 117-120. doi: $10.1080 / 13674679908406340$

Hayes, A. F. (2013). Introduction to mediation, moderation, and conditional process analysis: A regressionbased approach. Guilford Publications.

Horley, J., \& Lavery, J. J. (1995). Subjective well-being and age. Social Indicators Research, 34(2), 275-282. doi: 10.1007/bf01079200

Ismail, F. (1995). Islam, Politics and Ideology in Indonesia: A Study of the Process of Muslim Acceptance of the Pancasila (Doctoral dissertation, McGill University Libraries).
Ihsanudin. (2018, Maret 9). Kompas.com. Retrieved Juni 4, 2018, from Peta Koalisi Pilpres 2019: https://nasional.kompas.com/read/2 018/03/09/08094961/peta-koalisipilpres-2019-dan-kemiripannyadengan-pilkada-dki?page=all

Lucas, R. E. (2005). Time does not heal all wounds: A longitudinal study of reaction and adaptation to divorce. Psychological science, 16(12), 945950. doi: 10.1111/j.14679280.2005.01642.x

McCullough, M. E., \& Willoughby, B. L. B. (2009). Religion, self-control, and self-regulation: Associations, explanations, and implications. Psychological Bulletin, 135, 69-93. doi: 10.1037/a0014213

Mroczek, D. K., \& Spiro III, A. (2005). Change in life satisfaction during adulthood: Findings from the veterans affairs normative aging study. Journal of personality and social psychology, 88(1), 189. Doi: 10.1037/0022-3514.88.1.189

Muluk, H, dkk. (2018). Political Ideology Scale. Jurnal masih dalam penyusunan.

Napier, J. L., \& Jost, J. T. (2008). Why are conservatives happier than liberals? Psychological Science, 19, 565-572. doi: 10.1111/j.14679280.2008.02124.x

Peterson, C., \& Seligman, M. E. P. (2004). Character strengths and virtues: $A$ handbook and classifi cation. New York, NY: Oxford University Press.

Rosalina, M. P. K. (2013). Kontribusi Spiritualitas dan Religiusitas Terhadap Resiliensi Keluarga Pada Mahasiswa dengan Latar Belakang Keluarga Miskin. (Unpublished undergraduate thesis). Universitas Indonesia, Depok.

Ryff, C. D. (1989). Happiness is everything, or is it? Explorations on the meaning of psychological wellbeing. Journal of personality and social psychology, 57(6), 1069. doi: 
10.1037//0022-3514.57.6.1069

Schlenker, B. R., Chambers, J. R., \& Le, B. M. (2012). Conservatives are happier than liberals, but why? Political ideology, personality, and life satisfaction. Journal of Research in Personality, 46(2), 127-146. doi: 10.1037/e634112013-533

Seligman, M. E., Steen, T. A., Park, N., \& Peterson, C. (2005). Positive psychology progress: empirical validation of interventions. American psychologist, 60(5), 410. doi: 10.1037/0003-066x.60.5.410

Washburn, A. N., \& Skitka, L. J. (2016). Are conservatives from Mars and Liberals from Venus? Maybe not so much. In P. Valdesolo \& J. Graham (Eds.), Social Psychology of Political Polarization (pp. 88-111). Routledge.

Soydemir, G. A., Bastida, E., \& Gonzalez, G. (2004). The impact of religiosity on selfassessments of health and happiness: Evidence from the US Southwest. Applied Economics, 36, 665-672. doi: 10.1080/ 0003684042000222052

Stavrova, O., \& Luhmann, M. (2016). Are conservatives happier than liberals?
Not always and not everywhere. Journal of Research in Personality, 63, 29-35. doi: 10.1016/j.jp.2016.04.011

Steger, M. F., \& Frazier, P. (2005). Meaning in life: One link in the chain from religiousness to well-being. Journal of Counseling Psychology, 52(4), 574-582. doi: 10.1037/00220167.52 .4 .574

Taylor, P., Funk, C., \& Craighill, P. (2006). Are we happy yet.

Worthington, E. L., Jr. (1988). Understanding the values of religious clients: A model and its application to counseling. Journal of Counseling Psychology, 35, 166-174. doi: 10.1037/0022-0167.35.2.166

Worthington, E. L., Wade, N. G., Hight, T. L., Ripley, J. S., McCullough, M. E., Berry, J. W., Berry, J. T., Berry, J. W., Schmitt, M. M. Busrley, K. H. \& O'connor, L. (2003). The Religious Commitment Inventory-10: Development, refinement, and validation of a brief scale for research and counseling. Journal of Counseling Psychology, Vol. 50, No. 1, 84-96. doi: 10.1037/0022-0167.50.1.84 